\title{
PENGARUH PENERAPAN ENTERPRISE RESOURCE PLANNING TERHADAP KINERJA PERUSAHAAN MANUFAKTUR DENGAN FIRM SIZE SEBAGAI VARIABEL MODERASI
}

\author{
Ruby Ketsiama Meijer P* dan Hendra Gunawan* \\ Politeknik Negeri Batam \\ Program Studi Akuntansi Manajerial, \\ Jl. Ahmad Yani, Batam Centre, Batam 29461, Indonesia \\ E-mail: rubyketsiama@yahoo.com \\ * Politeknik Negeri Batam \\ Jl. Ahmad Yani, Batam Centre, Batam 29461, Indonesia \\ E-mail: hendra@polibatam.ac.id
}

\begin{abstract}
Abstrak
Penelitian ini bertujuan untuk menguji pengaruh penerapan enterprise resource planning terhadap kinerja perusahaan manufaktur yang dimoderasi oleh ukuran perusahaan yang terdaftar di BEI periode 2013-2015.Ukuran perusahaan dilihat melalui penjualan dan total aset. Sampel diambil dengan menggunakan purposive sampling dan memenuhi kriteria sampel. Teknik analisis yang digunakan dalam penelitian ini adalah analisis regresi berganda. Hasil penelitian menunjukkan bahwa penerapan enterprise resource planning mempengaruhi kinerja perusahaan secara signifikan yang diperkuat dengan tingkat penjualan yang tinggi dan juga mempengaruhi kinerja perusahaan secara signifikan yang diperkuat dengan total aset yang besar. Tingginya penjualan dan besarnya total aset dapat meningkatkan kinerja perusahaan yang menerapkan ERP. Kedua faktor tersebut memiliki pengaruh yang signifikan. Hasil dari penelitian ini diharapkan dapat menambah literatur penelitian mengenai faktor-faktor yang memperkuat kinerja perusahaan manufaktur yang menerapkan ERP. Penelitian selanjutnya dapat mengganti ukuran perusahaan yang dilihat dari pendapatan atau jumlah karyawan.
\end{abstract}

Kata Kunci: Kinerja perusahaan, enterprise resource planning, penjualan, total aset.

\begin{abstract}
This study aims to examine the effect of enterprise resource planning implementation on the performance of manufacturing companies moderated by the size of companies listed on the IDX period 2013-2015. Company size is seen through sales and total assets. Samples were taken by using purposive sampling and meeting the sample criteria. The analysis technique used in this research is multiple regression analysis. The results show that the implementation of enterprise resource planning significantly affects the company's performance is reinforced by high sales level and also affect the company's performance significantly reinforced by a large asset. The high sales and total assets can improve the performance of companies implementing ERP. Both of these factors have a significant influence. The results of this study are expected to add to the research literature on the factors that strengthen the performance of manufacturing companies that implement ERP. Future research can change the size of the company viewed from the income or the number of employees.
\end{abstract}

Keywords: Enterprise performance, enterprise resource planning, sales, total assets. 


\section{Pendahuluan}

Pesatnya pertumbuhan industri di Indonesia saat ini membuat perusahaan-perusahaan yang telah lama berdiri untuk terus bersaing agar dapat bertahan dalam menanggapi persaingan yang semakin pesat pula. Mulai dari perusahaan kecil hingga perusahaan besar terus bersaing dan menggunakan banyak cara untuk meningkatkan produktivitas serta kinerjanya. Perusahaan dengan kinerja yang baik adalah perusahaan yang dapat memenuhi fungsinya. Terry (2010) mengemukakan bahwa terdapat empat bagian fungsi manajemen, yakni planning (perencanaan), organizing (pengorganisasian), actuating (pelaksanaan), dan controlling (pengawasan).

Perkembangan teknologi yang tumbuh dengan pesat di dunia yang modern mengharuskan perusahaan untuk menerapkan sistem informasi untuk memperlancar aktivitas perusahaan agar lebih efektif dan efisien. Tahap prosedur formal yaitu saat data dikumpulkan, diproses menjadi informasi dan didistribusikan ke para pengguna disebut sistem informasi (Hall, 2009). Pemahaman mengenai sistem tersebut diharapkan mampu membuat aktivitas perusahaan berjalan sesuai dengan apa yang telah direncanakan.

Penerapan enterprise resource planning atau ERP merupakan salah satu cara yang banyak diterapkan pada perusahaan-perusahaan di dunia untuk mengintegrasikan sistem informasi satu dengan sistem informasi lainnya yang terdapat di dalam perusahaan, termasuk di Indonesia untuk meningkatkan kinerja maupun kualitas produk yang mereka hasilkan. Hall (2009) mendefinisikan enterprise resource planning sebagai model sistem informasi yang memungkinkan perusahaan mengotomatisasi dan mengintegrasi berbagai proses bisnis utama suatu perusahaan atau organisasi. Diharapkan dengan diterapkannya ERP dalam perusahaan mampu menghasilkan kinerja yang tinggi sesuai tujuan yang diinginkan.

Menanggapi semakin meningkatnya persaingan perdagangan di Indonesia membuat perusahaanperusahaan dalam negeri untuk terus meningkatkan kinerja masing-masing. Banyak cara yang dilakukan pihak perusahaan agar dapat bersaing dan bertahan dalam dunia perdagangan untuk terus meningkatkan kinerjanya. Cara tersebut tentu dengan adanya keunggulan kompetitif atau keunggulan bersaing untuk memiliki kinerja yang lebih tinggi dibanding perusahaan lain pada industri atau pasar yang sama. Tangkilisan (2003) mengemukakan bahwa keunggulan kompetitif adalah sesuatu yang merujuk pada kemampuan sebuah organisasi untuk memformulasikan strategi yang menempatkannya pada suatu posisi yang menguntungkan dibanding dengan perusahaan lainnya.

Perusahaan besar maupun perusahaan kecil yang menjalankan empat bagian fungsi manajemen tentunya membutuhkan informasi sebagai dasar dalam membuat kebijakan dan pengambilan keputusan. Bodnar (2000) mendefinisikan informasi sebagai sebuah data yang diolah sehingga dapat dijadikan dasar untuk mengambil keputusan yang tepat. Tentunya informasi yang digunakan harus memiliki karakteristik yaitu relevan, tepat waktu, akurasi, kelengkapan, dan ringkas (Hall, 2009).

Melihat hasil atau kinerja yang diinginkan perusahaan, tentunya terdapat cara untuk mengukur hal tersebut. Alat untuk mengukur kinerja perusahaan adalah dengan melakukan analisis berikut, yaitu: economic value added (EVA), return on asset (ROA), return on equity (ROE), return on investment (ROI), return on sales (ROS), earnings per share (EPS) dan Tobin's Q. Melalui angka-angka yang tercantum dalam laporan keuangan perusahaan, maka kinerja perusahaan juga dapat terukur dengan melakukan analisis tersebut.

Penelitian ini merupakan penelitian yang direplikasi dari penelitian yang dilakukan oleh Bohorquez \& Estevez (2008). Peneliti menguji ukuran perusahaan sebagai moderator dalam pengaruh penerapan sistem ERP terhadap kinerja perusahaan. Penelitian sebelumnya menemukan adanya pengaruh moderasi yang signifikan dari ukuran perusahaan dalam pengaruh penerapan sistem ERP terhadap kinerja perusahaan hanya pada kelompok perusahaan yang memiliki pendapatan tahunan yang tinggi. Penelitian ini akan melakukan kembali pengujian 
pengaruh penerapan sistem ERP terhadap kinerja perusahaan dengan ukuran perusahaan sebagai moderator. Perbedaan penelitian ini dengan penelitianpenelitian sebelumnya adalah penelitian ini menggunakan analisis Tobin's Q dalam mengukur kinerja perusahaan. Perusahaan yang akan diteliti lebih spesifik yaitu hanya dalam ruang lingkup perusahaan manufaktur saja mengingat perusahaan manufaktur merupakan perusahaan yang paling banyak menerapkan ERP. Tujuannya adalah untuk mendapatkan hasil yang lebih akurat dan spesifik dibanding dengan penelitian sebelumnya.

\section{Perumusan Masalah}

Berdasarkan latar belakang masalah yang telah diuraikan di atas, maka rumusan masalah yang diajukan dalam penelitian ini adalah bagaimana pengaruh ukuran perusahaan yang diukur dengan penjualan dalam memoderasi penerapan sistem ERP terhadap kinerja perusahaan menufaktur di Indonesia dan bagaimana pengaruh ukuran perusahaan yang diukur dengan total aset dalam memoderasi pengaruh penerapan sistem ERP terhadap kinerja perusahaan manufaktur di Indonesia.

\section{Landasan Teori}

\section{Teori Keagenan (Agency Theory)}

Hubungan keagenan di dalam teori agensi menurut Jensen \& Meckling (1967), menjelaskan bahwa perusahaan merupakan kumpulan kontrak antara pemilik sumber daya ekonomis (principal) dan manager (agent) yang mengurus penggunaan dan pengendalian sumber daya tersebut. Teori keagenan merupakan dasar yang digunakan untuk melihat kinerja perusahaan. Principal mempekerjakan agent untuk melakukan tugas untuk kepentingan principal, termasuk pendelegasian otorisasi pengambilan keputusan dari principal kepada agent. Perusahaan yang modalnya terdiri atas saham, pemegang saham bertindak sebagai principal dan chief executive officer (CEO) sebagai agent mereka.

Konsep teori keagenan menjelaskan terdapat hubungan atau kontrak antara pemegang saham atau pemilik sebagai principal dan manajemen perusahaan sebagai agent. Saat agenttidak berbuat sesuai kepentingan principal, maka akan terjadi konflik keagenan (agency conflict) yang memicu munculnya biaya keagenan (agency cost), sehingga diperlukan kesepakatan kerja yang tertuang dalam contract performance. Sebagai agent, manajer ditunjuk oleh pemegang saham sebagai pemilik perusahaan untuk mengoperasikan perusahaan. Pemegang saham menginginkan pengembalian yang lebih besar dan secepat-cepatnya atas investasi yang mereka tanamkan, sedangkan manajer menginginkan kepentingannya diakomodasi dengan pemberian kompensasi atau insentif yang sebesar-besarnya atas kinerjanya dalam menjalankan perusahaan.

\section{Teori Kontijensi (Contigency Theory)}

Thompson (1967) dalam Zeithaml et al. (1960) mengembangkan teori kontijensi berdasarkan dampak dari teknologi terhadap organsasi. Kekuatan teknologi dan lingkungan akan berpengaruh terhadap organisasi di mana organisasi yang memiliki teknologi yang kurang lebih sama akan memiliki perilaku organisasi yang kurang lebih sama pula. Teori kontijensi yang dikembangkan oleh Woodward (1965) dalam Zeithaml et al. (1960) melalui studinya mengenai efek atau dampak dari teknologi terhadap organisasi menjelaskan adanya hubungan secara langsung antara teknologi dengan struktur sosial organisasi. Organisasi yang menerapkan teknologi canggih, cenderung mengembangkan struktur organisasi yang sesuai dengan kecanggihan teknologi itu. Besar atau kecilnya sebuah perusahaan tergantung pada struktur organisasi yang ada di perusahaan tersebut.

\section{Teori Sinyal (Signalling Theory)}

Signalling theory atau teori sinyal dikembangkan oleh Ross (1977) yang menyatakan bahwa pihak eksekutif perusahaan memiliki informasi lebih baik mengenai perusahaan akan terdorong untuk menyampaikan informasi tersebut kepada calon investor agar harga saham perusahaannya meningkat. Hal positif dalam signalling theory yaitu saat perusahaan yang memberikan informasi yang bagus akan membedakan mereka dengan perusahaan yang 
tidak memiliki "berita bagus" dengan menginformasikan pada pasar tentang keadaan mereka, sinyal tentang bagusnya kinerja masa depan yang diberikan oleh perusahaan yang kinerja keuangan masa lalunya tidak bagus tidak akan dipercaya oleh pasar (Wolk \& Tearney, 2010).

Manajer pada umumnya termotivasi untuk menyampaikan informasi yang baik mengenai perusahaannya ke publik secepat mungkin, misalnya melalui jumpa pers. Namun pihak di luar perusahaan tidak tahu kebenaran dari informasi yang disampaikan tersebut. Jika manajer dapat memberi sinyal yang meyakinkan, maka publik akan terkesan dan hal ini akan terefleksi pada harga sekuritas. Jadi dapat disimpulkan karena adanya asymetric information, pemberian sinyal kepada investor atau publik melalui keputusan-keputusan manajemen menjadi sangat penting (Atmaja, 2008).

\section{Kinerja Perusahaan}

Perusahaan yang memiliki kinerja baik merupakan perusahaan yang menguntungkan bagi stakeholder. Kinerja perusahaan merupakan hasil dari kegiatan perusahaan dalam mengelola keseluruhan sumber daya yang dimiliki dalam pencapaian tujuan perusahaan. Bagi para pemilik perusahaan, menilai kinerja manajemen untuk menjamin bahwa harta yang diinvestasikan dalam perusahaan itu digunakan secara baik dan sesuai dengan tujuannya. Penilaian kinerja menurut Mulyadi (2001) adalah penentuan secara periodik efektivitas operasional suatu organisasi, bagian organisasi, dan karyawannya berdasarkan sasaran standar dan kriteria yang telah ditetapkan sebelumnya. Standar tersebut berupa kebijakan manajemen atau rencana formal yang dituangkan dalam rencana stratejik, program, dan anggaran organisasi. Kinerja perusahaan dapat dinilai melalui berbagai macam metode seperti ROA, ROE, ROI, sales growth, dan sebagainya, dalam penelitian ini kinerja diukur dengan Tobin's Q. Tobin's Q atau yang dikenal juga sebagai $\mathrm{Q}$ ratio mengukur kesempatan berkembang suatu perusahaan yang dihitung dengan cara market value equity ditambah dengan total hutang lalu di bagi dengan total aktiva perusahaan (Tobin,
1969).

\section{Metode Penelitian, Hasil dan Pembahasan}

\section{Metode Penelitian}

\section{Jenis dan Sumber Data}

Metode penelitian yang digunakan penelitian ini adalah metode pendekatan kuantitatif. Metode pendekatan kuantitatif ini bertujuan untuk mengukur hubungan variabel independen berupa penerapan sistem ERP terhadap kinerja perusahaan manufaktur di Indonesia yang dimoderasi dengan ukuran perusahaan. Data yang digunakan dalam penelitian ini merupakan data sekunder berupa laporan keuangan tahunan perusahaan manufaktur yang terdaftar di Bursa Efek Indonesia (BEI) untuk periode 2013-2015. Data laporan keuangan diperoleh melalui situs www.idx.co.id.

\section{Variabel Dependen}

Variabel dependen pada penelitian ini adalah kinerja perusahaan. Kinerja perusahaan merupakan gambaran pencapaian pelaksanaan suatu kegiatan atau kebijaksanaan dalam mewujudkan sasaran, visi dan misi perusahaan (Widamunti, 2010). Penelitian ini menggunakan metode Tobin's Q, jika nilai Tobin's Q mendekati atau lebih besar dari 1 menggambarkan bahwa perusahaan memiliki kinerja yang baik, semakin besar nilai Tobin's Q semakin baik kinerja perusahaan, sebaliknya jika nilai Tobin's Q lebih kecil dari 1 menggambarkan bahwa perusahaan memiliki kinerja yang tidak baik, semakin kecil nilai Tobin's Q semakin buruk kinerja perusahaan. Menurut Tobin (1969) nilai Tobin's Q dapat dirumuskan sebagai berikut:

Tobin's $Q=\frac{\text { TotalDebt }+ \text { Market Capitalizatipn }}{\text { Book Value of Assets }}$

\section{Variabel Independen}

Variabel independen pada penelitian ini adalah penerapan sistem ERP pada perusahaan manufaktur yang terdapat di Bursa Efek Indonesia (BEI) dan OJK. Penerapan sistem ERP ini akan memberikan gambaran bagaimana efektifitas dan efisiensi dari sistem yang 
digunakan. Proses pengolahan data untuk penerapan sistem ERP dilakukan dengan mengklasifikasikan ke dalam dua kelompok yaitu apabila perusahaan menerapkan sistem ERP maka akan diberikan skor 1 dan apabila tidak menerapkan sistem ERP maka akan diberikan skor 0 . Hal ini dilakukan karena penelitian ini menggunakan data dummy.

\section{Variabel Moderasi}

Variabel moderasi pada penelitian ini adalah ukuran perusahaan. Alat ukur yang digunakan untuk menilai variabel ini adalah dengan melihat penjualan dan total aset seperti yang telah dispesifikasikan sebelumnya. Formulanya:

\begin{tabular}{|l|}
\hline \\
\hline Ukuran perusahaan $=\log$ dari total asset \\
\hline Sumber: Ferry \& Jones $[2001)$
\end{tabular}

$$
\begin{aligned}
& \text { Perusahaan Kecil dan Menengah = Pendapatan <1 Milyar Rupiah } \\
& \text { Perusahaan Menengah dan Besar = Pendapatan >1 Milyar Rupiah }
\end{aligned}
$$

\section{Sumber: UU No.9 tahun 1995}

\section{Teknik Penarikan Sampel}

Populasi penelitian ini adalah seluruh perusahaan yang terdaftar di BEI dan OJK selama periode 20132015. Proses pemilihan sampel menggunakan metode purposive sampling. Metode purposive sampling adalah penentuan sampel berdasarkan kriteria yang telah dirumuskan terlebih dahulu oleh peneliti (Siagian \& Sugiarto, 2002). Kriteria perusahaan yang dijadikan sampel dalam penelitian ini adalah sebagai berikut:

a. Perusahaan manufaktur yang terdapat di BEI dan OJK selama periode penelitian (2013-2015).

b. Data yang dibutuhkan tersedia dengan lengkap dan menerbitkan laporan keuangan yang telah diaudit oleh auditor independen dari tahun 2013-2015.

c. Menggunakan periode laporan keuangan mulai 1 Januari sampai 31 Desember dan menggunakan rupiah sebagai mata uang pelaporan.

\section{Tabel 1 Karakteristik Sampel}

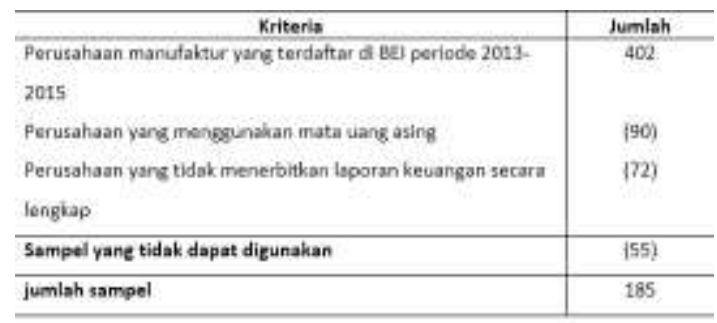

Sumber Data yang dioiah deryan MS Exicl.

\section{Teknik Pengumpulan Data}

Teknik pengumpulan data yang digunakan adalah arsip basis data untuk memperoleh data sekunder yang diakses melalui situs BEI dan situs OJK untuk data laporan keuangan dan data primer yaitu dengan cara menghubungi pihak perusahaan untuk mengetahui adanya penerapan ERP di perusahaan tersebut. Data yang digunakan dalam penelitian ini adalah time series.

\section{Teknik Pengolahan Data}

Pengolahan data yang digunakan dalam penelitian ini adalah dengan menggunakan SPSS versi 17. Penelitian ini menggunakan tiga langkah dalam mengelola data yang telah diperoleh dari responden. Tahapan pertama dimulai dengan pengeditan (editing), tujuannya adalah untuk meneliti kembali apakah laporan keuangan perusahaan yang akan diteliti sudah cukup baik sebagai upaya menjaga kualitas data agar dapat diproses lebih lanjut. Tahapan yang kedua adalah pemberian kode (coding) pada variabel penelitian. Tahapan yang ketiga adalah tabulasi (tabulating), di mana data yang telah diperoleh disusun dalam bentuk tabel distribusi frekuensi.

\section{Teknik Analisis Data}

Berdasarkan jenis data yang digunakan dalam penelitian ini, maka teknik analisis data yang digunakan dalam penelitian ini terdiri atas analisis statistik deskriptif, uji asumsi klasik, uji statistik simultan (uji F). Stastistik deskriptif digunakan untuk melukiskan data penelitian. Data penelitian meliputi mean, maximum, minimum, dan standar deviasi. Uji asumsi klasik dilakukan agar parameter pengujian yang digunakan dinyatakan valid. Analisis regresi sederhana digunakan untuk mengetahui besarnya 
pengaruh variabel independen terhadap variabel dependen.

\section{Uji Asumsi Klasik}

Uji asumsi klasik digunakan untuk menguji ketepatan model. Uji asumsi klasik yang akan digunakan adalah:

\section{Uji Normalitas}

Uji ini bertujuan untuk menguji apakah model regresi, variabel bebas dan variabel terikatnya berdistribusi normal. Normalitas data dapat dilihat dengan menggunakan uji normal kolmogorov-smirnov. Kriteria pengambilan keputusannya adalah jika sig > 0,05 maka data terdistribusi normal dan jika sig $<0,05$ maka data tidak terdistribusi normal (Ghozali, 2012).

2. Uji Multikolonieritas

Uji multikolonearitas bertujuan untuk menguji apakah model regresi ditemukan adanya korelasi antar variabel bebas (Ghozali I., 2012). Pada penelitian ini uji multikolinearitas tidak dilakukan karena hanya menguji satu variabel independen dan satu variabel dependen dalam setiap model regresi. Menurut Gujarati (2006), uji multikolinearitas dilakukan untuk menguji ada tidaknya hubungan linear yang benar-benar pasti diantara variabel-variabel penjelas yang tercakup dalam regresi berganda.

3. Uji Heteroskedastisitas

Uji ini bertujuan untuk menguji apakah dalam model regresi terjadi ketidaksamaan variance dari residual satu pengamatan ke pengamatan lain. Nilai signifikan korelasi $>0,05(\alpha=5 \%)$ maka dapat disimpulkan tidak terjadi heteroskedastisitas (Ghozali, 2012).

4. Uji Autokorelasi
Uji autokorelasi bertujuan menguji apakah dalam model regresi linear ada korelasi antar kesalahan pengganggu pada periode $\mathrm{t}$ dengan kesalahan pengganggu pada periode $\mathrm{t}-1$ (sebelumnya) (Ghozali, 2012). Pada penelitian ini uji autokorelasi tidak dilakukan karena merupakan data cross section. Hal ini sering ditemukan pada data runtut waktu (time series), masalah autokorelasi relatif jarang terjadi karena gangguan pada obvervasi yang berbeda berasal dari individu atau kelompok yang berbeda (Ghozali, 2012).

\section{Pengujian Hipotesis}

Uji hipotesis dilakukan untuk mengetahui pengaruh antar variabel dependen (X1) dengan independen (Y) dengan adanya variabel moderasi (X2). Analisis data yang digunakan dalam penelitian ini adalah time series. Adapun model persamaan regresi dalam penelitian ini adalah:

$K P M I=\alpha+\beta_{1} E R P+\beta_{2} F S+\beta_{3} E R P . F S+\varepsilon$

Keterangan:

$$
\begin{array}{ll}
\alpha & =\text { Konstanta } \\
\beta_{1-} \beta_{3} & =\text { Koefisien Regresi } \\
\text { KPMI } & =\text { Tobin's Q } \\
\text { ERP } & =\text { Enterprise Resourse Planning } \\
\text { FS } & =\text { Firm Size (Penjualan dan Total Aset) } \\
\varepsilon & =\text { Error Term }
\end{array}
$$

\section{Hasil dan Pembahasan}

\section{Hipotesis}

\section{Pengaruh Penerapan ERP terhadap Kinerja Perusahaan Manufaktur yang dimoderasi oleh Penjualan}

Ukuran perusahaan merupakan salah satu faktor yang menentukan kemampuan perusahaan dalam menghasilkan laba. Semakin besar perusahaan, 
biasanya mereka mempunyai kekuatan tersendiri dalam menghadapi masalah bisnis didukung oleh besarnya penjualan. Besarnya penjualan biasanya merefleksikan besarnya suatu perusahaan dari kemampuannya menghasilkan pendapatan dari kegiatan operasionalnya.

Skala perusahaan menunjukkan besarnya suatu ukuran (besar atau kecil) dari suatu perusahaan atau badan usaha Edilius (1992). Menurut UndangUndang Nomor 9 tahun 1995 tentang usaha kecil point

b, menjelaskan bahwa "perusahaan yang memiliki hasil penjualan tahunan paling banyak satu milyar rupiah digolongkan kelompok usaha kecil”. Ketentuan ini menyatakan bahwa perusahaan yang memiliki hasil

penjualan tahunan di atas satu milyar rupiah dapat dikelompokkan ke dalam industri menengah dan besar.

Perusahaan yang bergerak di bidang manufaktur sebagai perusahaan yang paling banyak menerapkan ERP, diharapkan mampu mewakili seluruh perusahaan yang ada di Indonesia. Penelitian ini juga pernah diteliti di India oleh beberapa peneliti antara lain Banwait \& Laroiya (2010) dalam

penelitiannya peneliti menemukan bahwa tingkat penjualan mampu memoderasi pengaruh penerapan ERP terhadap kinerja perusahaan, sehingga hipotesis yang akan diuji adalah:

H1: Penjualan memoderasi pengaruh penerapan sistem ERP terhadap kinerja perusahaan manufaktur di Indonesia.

\section{Pengaruh Penerapan ERP terhadap Kinerja Perusahaan Manufaktur yang dimoderasi oleh Total Aset}

Semakin besar perusahaan, juga membuat mereka mempunyai kekuatan tersendiri dalam menghadapi masalah bisnis dan kemampuan perusahaan dalam menghasilkan laba tinggi karena didukung oleh besarnya total aset yang dimiliki. Hal ini membuat kendala perusahaan seperti peralatan yang memadai dan sejenisnya dapat teratasi. Ukuran perusahaan juga merupakan besar kecilnya suatu perusahaan yang diukur dari besarnya total aset atau kekayaan yang dimiliki oleh suatu perusahaan.
Keputusan OJK pada dasarnya juga menggolongkan ukuran perusahaan dalam dua kelompok, yaitu sebagai berikut:

a. Perusahaan menengah dan kecil merupakan badan hukum yang memiliki sejumlah kekayaan (total aset) tidak lebih dari 20 milyar rupiah, bukan merupakan afiliasi atau dikendalikan oleh suatu perusahaan yang bukan perusahaan menengah/kecil.

b. Perusahaan menengah dan besar merupakan perusahaan yang memiliki sejumlah kekayaan (total aset) lebih dari 20 milyar rupiah, melakukan kegiatan ekonomi yang mempunyai kriteria kekayaan bersih atau hasil penjualan tahunan usaha meliputi usaha nasional (milik negara atau swasta) dan usaha asing.

Penelitian ini juga pernah diteliti di Spanyol oleh Bohorquez \& Estevez (2008) dalampenelitiannya peneliti menemukan terdapat pengaruh positif antara penerapan ERP terhadap kinerja perusahaan manufaktur yang dimoderasi oleh total aset. Hasil penelitian menunjukkan bahwa total aset dapat memoderasi secara signifikan. Melihat ukuran perusahaan manufaktur yang juga dapat diukur dari total aset yang dimiliki setiap perusahaan maka dengan ini hipotesis yang akan diuji adalah:

H2: Total aset perusahaan memoderasi pengaruh penerapan sistem ERP terhadap kinerja perusahaan manufaktur di Indonesia.

Berdasarkan pengembangan hipotesis yang telah disajikan di atas, maka model dalam penelitian ini dapat dilihat pada Gambar 1 .

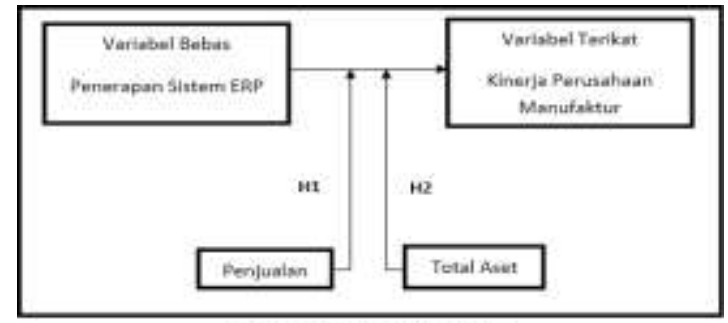

Gambar 2. 1 Medel Penelitiar

Sumber: tholah sendiri

Gambar 1

Statistik Deskriptif 
Tabel 2 Statistik Deskriptif

\begin{tabular}{lccccc}
\hline Variabel & N & Min & Max & Mean & $\begin{array}{c}\text { Standar } \\
\text { Deviasi }\end{array}$ \\
\hline ERP & 185 & 0 & 1 & 0,90 & 0,29 \\
Penjualan & 185 & 24,73 & 31,88 & 27,56 & 1,56 \\
Total Aset & 185 & 25,33 & 32,15 & 28,07 & 1,55 \\
Tobin's Q & 185 & 0,18 & 3,34 & 1,13 & 0,64 \\
\hline Sumber: Data yang diolah dengan SPSS 17.0 & & &
\end{tabular}

Berdasarkan Tabel 2 di atas, maka dapat diketahui bahwa jumlah data yang digunakan dalam penelitian ini adalah 185 data sampel. Penelitian ini menguji variabel dependen yaitu kinerja perusahaan manufaktur yang diukur dengan Tobin's Q dan variabel independen yaitu penerapan ERP dan variabel moderasi yaitu firm size yang diukur dengan penjualan dan total aset.

Berdasarkan statistik deskriptif Tabel 2 diketahui komponen pertama penjualan memiliki nilai minimum $\mathrm{Rp}$ 54.804.545.455 ( $\mathrm{LNP}=24,73)$, artinya jumlah penjualan yang dimiliki perusahaan manufaktur minumum sebesar Rp54.804.545.455, jumlah penjualan yang rendah menggambarkan kesulitan bagi perusahaan dalam meningkatkan kinerja perusahaan dan jumlah maksimum penjualan yang dimiliki perusahaan manufaktur sebesar Rp90.000.000.000.000 (LNP=31,88), jumlah penjualan yang besar menggambarkan kemampuan perusahaan dalam meningkatkan kinerja perusahaan. Nilai rata-rata penjualan Rp5.590.000.000.000 $(\mathrm{LNP}=27,8615)$ dan standar deviasinya adalah sebesar Rp13.930.000.000.000 (LNP=1,58114) artinya bahwa perbedaan data sampel berjarak sebesar 1,58114 dari rata-rata dan nilai rata-rata lebih besar dari pada standar deviasi sehingga mengindikasikan hasil yang cukup baik karena semakin kecil nilai standar deviasi maka keragaman data sampel semakin kecil.

Komponen kedua total aset memiliki nilai minimum sebesar Rp99.000.000.000 (LNTA=25,33), artinya perusahaan sampel mempunyai total aset pada perusahaan manufaktur sebesar Rp99.000.000.000 dan maksimum total aset Rp90.920.000.000.000
(LNTA=32,15). Nilai rata-rata sebesar Rp5.310.000.000.000 (LNTA=28,0714) dan nilai standar deviasi sebesar Rp12.700.000.000.000 (LNTA=1,54524), artinya bahwa perbedaan data sampel berjarak sebesar dari 1,54524 dari rata-rata dan nilai rata-rata lebih besar dari pada standar deviasi sehingga mengindikasikan hasil yang cukup baik karena semakin kecil nilai standar deviasi maka semakin bagus penyebaran datanya.

Komponen ketiga Tobin's Q memiliki nilai minimum 0,18 dan nilai maksimum sebesar 3,34. Nilai rata-rata 1,1306 dan nilai standar deviasi sebesar 0,63906 artinya bahwa perbedaan data sampel berjarak sebesar 0,63906 dari rata-rata dan nilai rata-rata lebih besar dari pada standar deviasi sehingga mengindikasikan hasil yang cukup baik karena semakin kecil nilai standar deviasi maka semakin bagus penyebaran datanya.

Variabel penerapan ERP dapat juga dijelaskan lebih rinci dalam bentuk frekuensi, statistik deskriptif untuk variabel penerapanERP dapat dilihat pada Tabel 3 berikut.

\section{Tabel 3 Statistik Deskriptif Variabel Penerapan} Sistem ERP

\begin{tabular}{cccc}
\hline & Variabel & Frequency & Percent \\
\hline \multirow{2}{*}{ ERP } & ERP & 167 & $90,30 \%$ \\
& NON ERP & 18 & $9,70 \%$ \\
\hline TOTAL & & $\mathbf{1 6 0}$ & $\mathbf{1 0 0 , 0 0 \%}$ \\
\hline
\end{tabular}

Sumber: Data yang diolah dengan SPSS 17.0

Berdasarkan penerapan ERP pada perusahaan manufaktur dibagi ke dalam dua kategori yaitu yang menerapkan dan yang tidak menerapkan. Kode 1 untuk yang menerapkan ERP dan 0 jika tidak menerapkan ERP. Berdasarkan Tabel 3 perusahaan yang menerapkan ERP sebanyak 167 perusahaan (90,30\%) sedangkan perusahaan yang tidak menerapkan sebanyak 18 perusahaan $(9,30 \%)$.

\section{Uji Normalitas}


Tabel 4 Uji Normalitas

One-Sample Kolmogorov-Smirnov Test

\begin{tabular}{|c|c|}
\hline & $\begin{array}{c}\text { Unstandardized } \\
\text { Residual }\end{array}$ \\
\hline \multicolumn{2}{|l|}{ Kolmogarov-Sinirnov $Z$} \\
\hline Asymp, Sig. [2-railed $\}$ & \\
\hline
\end{tabular}

Berdasarkan Tabel 4, besarnya Kolmogorov-Smirnov nilai $\mathrm{Z}$ adalah 1,341 dan nilai signifikansinya adalah 0,055 . Nilai signifikansi tersebut lebih besar dari 0,05, sehingga dapat disimpulkan bahwa data residual berdistribusi normal.

\section{Uji Multikolonieritas}

\section{Tabel 5 Uji Multikolonieritas}

\begin{tabular}{ll}
\hline \multicolumn{1}{c}{ Model } & Sit \\
\hline Peserspan ERP & 002 \\
Penivalan & 000 \\
Total Aset & 879 \\
\hline Sumber: Data dialah dengan SPSS 17.0 &
\end{tabular}

Berdasarkan Tabel 5, besarnya signifikansi penjualan sebesar 0,000 dan signifikansi total aset sebesar 0,879 atau $87,9 \%$. Oleh karena korelasi ini masih di bawah 95\%, maka dapat dikatakan tidak terjadi multikolonieritas yang serius.

\section{Uji Heteroskedastistas}

Tabel 6 Uji Heteroskedastisitas

\begin{tabular}{|c|c|}
\hline Model & Sit \\
\hline Donersan EFo & 750 \\
\hline Panjuaiza & as? \\
\hline Total Aset & 894 \\
\hline
\end{tabular}

Tabel 6 menunjukkan bahwa tidak ada satupun variabel independen yang secara statistik mempengaruhi variabel depenpen nilai Absolute Ut (AbsUt). Hal ini terlihat dari probabilitas signifikansinya yaitu penerapan ERP 0,756 dan penjualan sebesar 0,857 serta signifikansi total aset sebesar 0,984 di atas tingkat kepercayaan 5\%, sehingga dapat disimpulkan model regresi tidak mengandung adanya heteroskedastisitas.

\section{Uji Autokorelasi}

Tabel 7 Uji Autokorelasi

\begin{tabular}{|c|c|c|c|c|c|}
\hline Nodel & $\mathrm{R}$ & R Square & $\begin{array}{c}\text { Agjusted R } \\
\text { Square }\end{array}$ & $\begin{array}{l}\text { Std. Encor of } \\
\text { the Estimate }\end{array}$ & $\begin{array}{l}\text { Derbin- } \\
\text { Watson }\end{array}$ \\
\hline 1 & $65^{2}$ & .424 & .45 & 48065 & 016 \\
\hline
\end{tabular}

Tabel 7 menunjukkan nilai DW sebesar 0,016 dan oleh karena nilai DW lebih besar daripada 0 dan lebih kecil dari batas bawah (dl) 1,706, maka dapat disimpulkan bahwa H0 tidak bisa ditolak yang menyatakan bahwa tidak ada autokorelasi positif atau dapat disimpulkan tidak terdapat autokorelasi.

\section{Pengujian Hipotesis}

Pengujian hipotesis dilakukan dengan menggunakan analisis regresi berganda serta uji simultan (uji f) yang diolah dengan menggunakan SPSS versi 17. Uji statistik menunjukkan seberapa jauh pengaruh satu variabel independen secara individual dalam menerangkan variasi variabel dependen.

\section{Hipotesis 1}

Hipotesis pertama yang diajukan dalam penelitian ini menyatakan bahwa penjualan memoderasi pengaruh penerapan ERP terhadap kinerja perusahaan manufaktur. Hipotesis ini dapat didukung apabila nilai signifikansinya menunjukkan nilai $<0,05$ dan tidak dapat didukung jika sebaliknya. Hasil analisis dapat dilihat pada Tabel 8.

Tabel 8 Hasil Uji Hipotesis Pertama (H1)

\begin{tabular}{|c|c|c|c|}
\hline Variabel & Koefisien & t-hitung & Sig. \\
\hline Kanutanta & $-5,600$ & $-8,731$ & 0,000 \\
\hline Ponerspan ERP & 0,002 & 3,143 & 0,002 \\
\hline Penjualan $\{$ HI $\}$ & 0.229 & 9,524 & $0,0 \infty 0$ \\
\hline R-Squart & 0.424 & & \\
\hline Adjustod R-Square & 0,418 & & \\
\hline
\end{tabular}

$K P M I=\alpha+\beta_{1} E R P+\beta_{2} F S+\beta_{3} E R P . F S$

$K P M I=0,402 \cdot E R P+0,229 \cdot F S+0,631 \cdot E R P \cdot F S$ 
Berdasarkan Tabel 8 di atas dapat dilihat bahwa variabel independen yaitu penerapan ERP signifikan mempengaruhi variabel dependen berupa kinerja perusahaan yang dimoderasi oleh penjualan pada taraf kepercayaan 95\%. Hal ini dibuktikan dengan singnifikansi sebesar 0,000 (lebih kecil dari $\alpha$ 5\%). Tanda positif pada koefisien variabel tersebut mengindikasi bahwa perusahaan yang menerapkan ERP, maka semakin tinggi kinerja perusahaan tersebut yang diperkuat dengan adanya penjualan yang tinggi. Nilai adjusted Adjusted $\mathrm{R}^{2}$ sebesar 0,418 menunjukkan bahwa variabel independen berupa penerapan ERP mampu menjelaskan variabel dependen berupa kinerja perusahaan sebesar $41,8 \%$ yang diperkuat dengan adanya penjualan yang tinggi, sedangkan sisanya sebesar 58,2\% dijelaskan oleh sebab-sebab lain di luar model.

\section{Hipotesis 2}

Hipotesis kedua yang diajukan dalam penelitian ini menyatakan bahwa besarnya total aset akan meningkatkan kinerja perusahaan. Hipotesis ini dapat didukung apabila nilai signifikansinya menunjukkan nilai < 0,05 dan tidak dapat didukung jika sebaliknya. Hasil analisis dapat dilihat pada Tabel 9.

Tabel 9 Hasil Uji Hipotesis Kedua (H2)

\begin{tabular}{|c|c|c|c|}
\hline Variabel & B & thitune & Sie. \\
\hline Konstanta & $-4,804$ & $-6,887$ & 0,000 \\
\hline Penerapan ERP & 0,642 & 4,913 & 0,000 \\
\hline Total Aset (H2) & 0,191 & 7,595 & $0,000 * *$ \\
\hline R-Square & 0,345 & & \\
\hline Adjusted R-Square & 0,338 & & \\
\hline
\end{tabular}

$K P M I=\alpha+\beta_{1} E R P+\beta_{2} F S+\beta_{3} E R P . F S$

$K P M I=0,642 \cdot E R P+0,191 \cdot F S+0,123 \cdot E R P . F S$

Berdasarkan Tabel 9 di atas dapat dilihat bahwa variabel independen yaitu penerapan ERP signifikan mempengaruhi variabel dependen berupa kinerja perusahaan manufaktur yang dimoderasi dengan total aset pada taraf kepercayaan 95\%. Hal ini dibuktikan dengan signifikansi sebesar 0,000 (lebih kecil dari $\alpha$ $5 \%$ ). Tanda positif pada koefisien variabel tersebut mengindikasi bahwa semakin besar total aset maka semakin tinggi pengaruh penerapan ERP terhadap kinerja perusahaan manufaktur. Nilai adjusted Adjusted $\mathrm{R}^{2}$ sebesar 0,338 menunjukkan bahwa penerapan ERP mampu menjelaskan kinerja perusahaan sebesar $33,9 \%$ yang diperkuat dengan besarnya total aset sedangkan sisanya sebesar $66,1 \%$ dijelaskan oleh sebab-sebab lain di luar model.

\section{Analisis Data}

Berdasarkan hasil uji hipotesis antara variabel independen dan variabel dependen serta variabel moderasi yaitu penerapan ERP sebagai variabel independen dan kinerja perusahaan manufaktur sebagai variabel dependen serta ukuran perusahaan sebagai variabel moderasi. Ringkasan hasil uji statistik dapat dilihat pada Tabel 10 .

Tabel 10 Ringkasan Hasil Uji Hipotesis

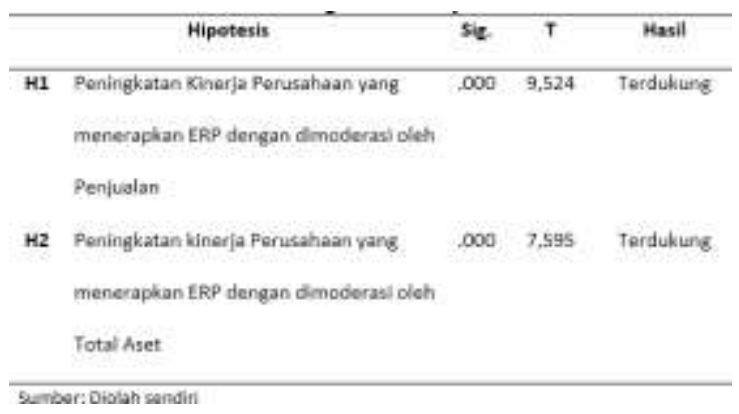

Berdasarkan Tabel 10 dapat dilihat bahwa nilai signifikansi pada hipotesis pertama adalah sebesar 0,000 atau berada di bawah 0,050 yang menyatakan bahwa $\mathrm{H} 1$ terdukung. Hal ini menjelaskan bahwa penerapan sistem ERP mempunyai pengaruh yang signifikan terhadap kinerja perusahaan manufaktur yang dimoderasi oleh tingginya tingkat penjualan. Nilai signifikansi pada hipotesis kedua adalah sebesar 0,000 atau berada di bawah 0,050 yang berarti bahwa $\mathrm{H} 2$ terdukung. Hal ini menyatakan bahwa penerapan sistem ERP berpengaruh terhadap kinerja perusahaan manufaktur yang dimoderasi oleh besarnya total aset.

\section{Pengaruh Penerapan ERP terhadap Kinerja Perusahaan Manufaktur yang dimoderasi oleh Penjualan}

Berdasarkan hasil uji statistik yang telah 
dijelaskan pada Tabel 10 menunjukkan terdapat pengaruh yang signifikan antara pengaruh penerapan ERP terhadap kinerja perusahaan manufaktur yang diperkuat dengan penjualan. Hal ini menyatakan bahwa hipotesis pertama (H1) terdukung. Hasil ini sesuai dengan penelitian Bohorquez \& Estevez (2008) yang menyatakan bahwa terdapat pengaruh yang signifikan antara penerapan ERP terhadap kinerja perusahaan manufaktur yang dimoderasi oleh pendapatan.

Hasil penelitian yang dilakukan oleh Banwait \& Laroiya (2010) juga menyatakan hal yang sama bahwa terdapat pengaruh yang signifikan antara penerapan sistem enterprise resource planning terhadap kinerja perusahaan yang dimoderasi oleh tingginya tingkat penjualan. Semakin tinggi tingkat penjualan maka semakin besar pula pengaruh yang ditimbulkan dari penerapan sistem ERP terhadap kinerja perusahaan tersebut.

\section{Pengaruh Penerapan ERP terhadap Kinerja Perusahaan Manufaktur yang dimoderasi oleh Total Aset}

Berdasarkan hasil uji statistik yang telah dijelaskan pada Tabel 10 menunjukkan terdapat pengaruh yang signifikan antara penerapan ERP terhadap kinerja perusahaan manufaktur yang diperkuat dengan total aset. Hal ini menunjukkan bahwa hipotesis kedua (H2) terdukung. Hasil ini sesuai dengan penelitian Bohorquez \& Estevez (2008) yang menyatakan bahwa total aset memiliki pengaruh yang signifikan dalam meningkatkan kinerja perusahaan yang menerapkan ERP.

Hasil penelitian ini juga sesuai dengan penelitian yang dilakukan oleh Banwait dan Laroiya (2010) yang menyatakan bahwa terdapat pengaruh yang signifikan antara penerapan sistem enterprise resource planning terhadap kinerja perusahaan yang menerapkannya dengan dimoderasi oleh besarnya total aset pada perusahaan tersebut. Semakin besar total aset maka semakin besar pula pengaruh penerapan sistem ERP terhadap kinerja perusahaan.

\section{Kesimpulan}

Penelitian dilakukan dengan tujuan untuk mengetahui pengaruh penerapan ERP terhadap kinerja perusahaan manufaktur yang terdaftar di Bursa Efek Indonesia (BEI) pada periode 2013-2015. Penulis melakukan penarikan sampel dan terdapat 80 perusahaan yang menjadi sampel dalam penelitian dengan jumlah data penelitian sebanyak 185 data peneltian. Data penelitian merupakan data sekunder berupa laporan keuangan dan telah bebas asumsi klasik. Berdasarkan hasil analisis dapat diambil kesimpulan sebagai berikut:

1. Terdapat pengaruh yang signifikan antara penerapan ERP terhadap kinerja perusahaan manufaktur yang dimoderasi oleh tingkat penjualan. Semakin tinggi tingkat penjualan maka semakin besar pula pengaruh penerapan ERP terhadap kinerja perusahaan tersebut. Hal ini karena tingginya tingkat penjualan perusahaan mampu meningkatkan kinerja perusahaan yang menerapkan ERP, sehingga tujuan dari perusahaan untuk meningkatkan kinerja tercapai.

2. Terdapat pengaruh yang signifikan antara penerapan ERP terhadap kinerja perusahaan manufaktur yang dimoderasi oleh besarnyatotal aset. Semakin besar total aset maka semakin besar pula pengaruh penerapan ERP terhadap kinerja perusahaan tersebut. Hal ini mengindikasi besarnya total aset mampu meningkatkan kinerja perusahaan yang menerapkan ERP.

\section{Keterbatasan dan Saran}

Keterbatasan pada penelitian ini terletak pada: Penelitian ini hanya dilakukan pada perusahaan manufaktur yang terdaftar di Bursa Efek Indonesia (BEI). Data sampel hanya berasal dari periode tiga tahun, yaitu tahun 2013-2015. Variabel dependen yang penulis gunakan hanya kinerja perusahaan saja yang diukur dengan tingkat penjualan dan besarnya total aset. Hal ini dikarenakan terbatasnya informasi yang disajikan oleh perusahaan pada setiap annual report. 
Berdasarkan hasil penelitian, maka saran yang dapat diberikan adalah: Penelitian selanjutnya diharapkan dapat menambah jumlah sampel, tidak hanya sebatas manufaktur di Indonesia saja, namun menambah sampel pada perusahaan manufaktur lain agar penelitian menjadi lebih luas. Penambahan jumlah tahun penelitian dapat menambah kualitas hasil penelitian menjadi lebih baik. Penelitian selanjutnya pada variabel diharapkan dapat menggunakan analisis lainnya dalam mengukur kinerja perusahaan seperti economic value added (EVA), return on asset (ROA), return on equity (ROE), return on investment (ROI), return on sales (ROS), earnings per share (EPS).

\section{Daftar Pustaka}

Atmadja, A. T., \& Saputra, K. A. (2014). The Effect Of Emotional Spiritual Quotatient To Ethical Behavior In Accounting profession With Tri Hita Karana Culture's As A Moderating Variable. Research Journal of finance and Accounting .

Bambang, \& Puspitasari, E. (2010). Tobin's Q and Altman Z.

Banwait, K., \& Laroiya, S. (2010). Performance evaluation of ERP Implementation in Indian SMEs. Journal of Manufacturing Technology, Vol. 21 No. 6, 759-780.

Bodnar, G. H. (2000). Sistem Informasi Akuntansi. Edisi keenam.

Bohorquez, V., \& Esteves, J. (2008). Analyzing SMEs Size as a Moderator of ERP. Communication of the Association for Information Systems (CAIS), Volume 8, Article 7.

Ferry, \& Jones. (2001). Manajemen Keuangan.

George H. Bodnar, W. S. (2000). Sistem Informasi Akuntansi. Jakarta: Buku Satu, Salemba Empat.

Ghozali. (2011). Analisis Multivariate Program SPSS. Semarang.
Ghozali, I. (2013). Aplikasi Analisis Multivariate dengan program SPSS. Semarang : Badan Penerbit Universitas Diponegoro.

Gujarati. (2006). Asumsi Klasik. Jakarta: Salemba Empat.

Hall, J. A. (2009). Accounting Information System. Jakarta: Salemba Empat.

Hartono, J. (2014). Metodologi Penelitian Bisnis. Yogyakarta: BPFE.

Hunton, J. L. (2003). Enterprise Resource Planning Systems: Comparing Firm Performance of Adopters and Non-Adopters. International Journal of Accounting Information Systems, 4(3), $165-184$

Jensen, M., \& Meckling, W. (1976). Theory of the firm: Managerial behavior, agency costs and owership structure. Journal of Financial Economics Vol. 3 (4), 305-306.

Jogiyanto. (2014). Metodologi Penelitian Bisnis : salah kaprah dan pengalaman-pengalaman. Yogyakarta: BPFE.

McColgan, P. (2001). Agency theory and corporate governance: a review of the literature from a UK percpective.

Sevilla, C. G. (2007). Research Methods. Quezon: Rex Printing Company.

Sugiyono. (2007). Statistika untuk Penelitian Bandung: CV Alfabeta.

Sujarweni, V. W. (2008). Belajar Mudah SPSS untuk Penelitian. Yogyakarta: Global Media Info.

Tangkilisan. (2003). Kebijakan Publik yang Membumi. Yogyakarta: Konsep.

Terry, G. d. (2010). Dasar-Dasar Manajemen. Cetakan kesebelas. Jakarta. 
Yamin, S., Rachmach, L. A., \& Kurniawan, H. (2011). Regresi dan Korelasi dalam Genggaman Anda. Jakarta: Salemba Empat.

Zeithaml, V. A., Varadarajan, P. R., \& Zeithaml, C. P. (1960). The Contingecy Approach: Its Foundations and Relevance to Theory Building and Research in Marketing. European Journal of Marketng, 37-64. 